\title{
Initial abstraction ratio and Curve Number estimation using rainfall and runoff data from a tropical watershed
}

\author{
Estimativa da razão de abstração inicial e Curve Number usando dados de chuva e vazão em \\ uma bacia tropical
}

\author{
Luiz Claudio Galvão do Valle Junior ${ }^{1}$, Dulce Buchala Bicca Rodrigues ${ }^{1}$ and Paulo Tarso Sanches de Oliveira ${ }^{1}$ \\ ${ }^{1}$ Universidade Federal do Mato Grosso do Sul, Campo Grande, MS, Brasil \\ E-mails: luizvallejr@gmail.com (LCGVJ), dulcebbr@gmail.com (DBBR),paulotarsoms@gmail.com (PTSO)
}

Received: December 26, 2017 - Revised: August 06, 2018 - Accepted: September 14, 2018

\begin{abstract}
The Curve Number $(\mathrm{CN})$ method is extensively used for predict surface runoff from storm events. However, remain some uncertainties in the method, such as in the use of an initial abstraction $(\lambda)$ standard value of 0.2 and on the choice of the most suitable CN values. Here, we compute $\lambda$ and $\mathrm{CN}$ values using rainfall and runoff data to a rural basin located in Midwestern Brazil. We used 30 observed rainfall-runoff events with rainfall depth greater than $25 \mathrm{~mm}$ to derive associated CN values using five statistical methods. We noted $\lambda$ values ranging from 0.005 to 0.455 , with a median of 0.045 , suggesting the use of $\lambda=0.05$ instead of 0.2 . We found a S0.2 to S0.05 conversion factor of 2.865. We also found negative values of Nash-Sutcliffe Efficiency (to the estimated and observed runoff). Therefore, our findings indicated that the $\mathrm{CN}$ method was not suitable to estimate runoff in the studied basin. This poor performance suggests that the runoff mechanisms in the studied area are dominated by subsurface stormflow.
\end{abstract}

Keywords: Hydrologic modeling; Rainfall-runoff events; CN; Ungauged basins.

\section{RESUMO}

O método Curve Number (CN) é amplamente usado na predição do escoamento superficial a partir de eventos de chuva. No entanto, existem algumas incertezas no método tais como no uso da abstração inicial $(\lambda)$ padrão igual a 0,2 e na escolha dos valores adequados de CN. Neste estudo, nós calculamos valores de $\lambda$ e CN usando dados de chuva e vazão para uma bacia rural localizada no Centro-oeste do Brasil. Nós usamos 30 dados observados de eventos de chuva e vazão com precipitação maior que 25 mm para calcular valores de $\mathrm{CN}$ a partir de cinco métodos estatísticos. Encontramos valores de $\lambda$ variando de 0,005 a 0,455 , com uma mediana igual 0,045 , sugerindo assim o uso de um valor de $\lambda=0,05$ ao invés de 0,2. Encontramos uma taxa de conversão de S0,2 para S0,05 de 2,865. Também verificamos valores negativos de Nash-Sutcliffe Efficiency (para valores de escoamento superficial estimado e observado). Portanto, nossos resultados indicaram que o método $\mathrm{CN}$ não foi adequado para estimar o escoamento superficial na bacia estudado. Essa fraca performance sugere que os mecanismos de escoamento na área estudada sejam dominados pelo escoamento subsuperficial.

Palavras-chave: Modelagem hidrológica; Eventos de chuva-vazão; CN; Bacias não monitoradas.

\section{INTRODUCTION}

Hydrological models are simplified representations of real environmental systems. Such models have been used as simulation and prediction tools that allow the most effective decision considering the environmental, social, and economic interactions of a real system (SOROOSHIAN et al., 2008). Rainfall-runoff is one of the most fundamental concepts in hydrology, serving as a starting point for flood peak estimation and structure design (HAWKINS; WARD; WOODWARD, 2009). The Curve Number (CN) method is an empirical rainfall-runoff model developed in the 1950s by the USDA Soil Conservation Service (SCS), now known as Natural Resources Conservation Service (NCRS), in response to the complexity of land use and the hydrological abstraction of rainfall (AJMAL et al., 2015). Several factors are integrated in the CN method, such as land cover and land use, surface condition, soil class, and antecedent 
runoff condition, which are combined in a single $\mathrm{CN}$ parameter (OLIVEIRA et al., 2016). Furthermore, this model covers three different usages; (1) give the return period direct runoff from the same return period rainfall depth; (2) explain rainfall-runoff for individual events; and (3) infer infiltration processes and soil moisture-CN relations (HAWKINS; WARD; WOODWARD, 2009).

The CN method has been the most used model for rainfall-runoff (AJMAL et al., 2015), and the main reasons for that are (1) calculation efficiency; (2) land cover and land use, soil class, and management practices data are easily obtainable; and (3) it generates suitable runoff estimates for agricultural and urban basins (YUAN et al., 2014).

The USDA-SCS developed a standard table of CN values using small agricultural basins in the United States (USDA, 1986). This table is documented in the NRCS National Engineering Handbook Part 630 (NEH 630), chapter 9. However, empirical evidence shows that use of tabulated $\mathrm{CN}$ normally over-designs the hydrological systems (LAL et al., 2016). The model parameters are the potential maximum retention $(\mathrm{S})$ and the initial abstraction (Ia) (ELHAKEEM; PAPANICOLAOU, 2009). The relation between Ia and $S$, defined as initial abstraction ratio $(\lambda)$, was originally determined to be 0.2 (USDA, 1997). However, many authors observed uncertainties in $\lambda$ results, and re-evaluated the selection of this value (ELHAKEEM; PAPANICOLAOU, 2009; SHI et al., 2009; WOODWARD et al., 2003; YUAN et al., 2014). In this context a modification of its value to 0.05 has been recommended (DURÁN-BARROSO; GONZÁLEZ; VALDÉS, 2017; WOODWARD et al., 2003; YUAN et al., 2014).

$\mathrm{CN}$ method is also one of the most widely used rainfallrunoff model in Brazil, and is recommended in government agencies handbooks (SARTORI; HAWKINS; GENOVEZ, 2011). However, tabulated $\mathrm{CN}$ values have not been fitted for Brazilian watersheds, mainly because few studies have been carried out to compute $\mathrm{CN}$ values using observed rainfall and runoff data (See ANDRADE et al., 2017; OLIVEIRA et al., 2016; SARTORI; HAWKINS; GENOVEZ, 2011). Therefore, in this study we evaluate the use of the $\mathrm{CN}$ method to estimate runoff in a tropical watershed. To achieve that, we determine initial abstraction ratio $(\lambda)$, and compute $\mathrm{CN}$ values using five statistical methods.

\section{MATERIAL AND METHOD}

\section{Study area}

This study was conducted in the Guariroba basin, located in the municipality of Campo Grande, MS, Brazil (Figure 1). This basin covers an area of 37,000 ha, however, in this study we used a drainage area of $31,571.27$ ha, delimited considering the discharge gauge as the basin outlet. The Guariroba basin is the main water supplier source for Campo Grande, which has 863.982 inhabitants.

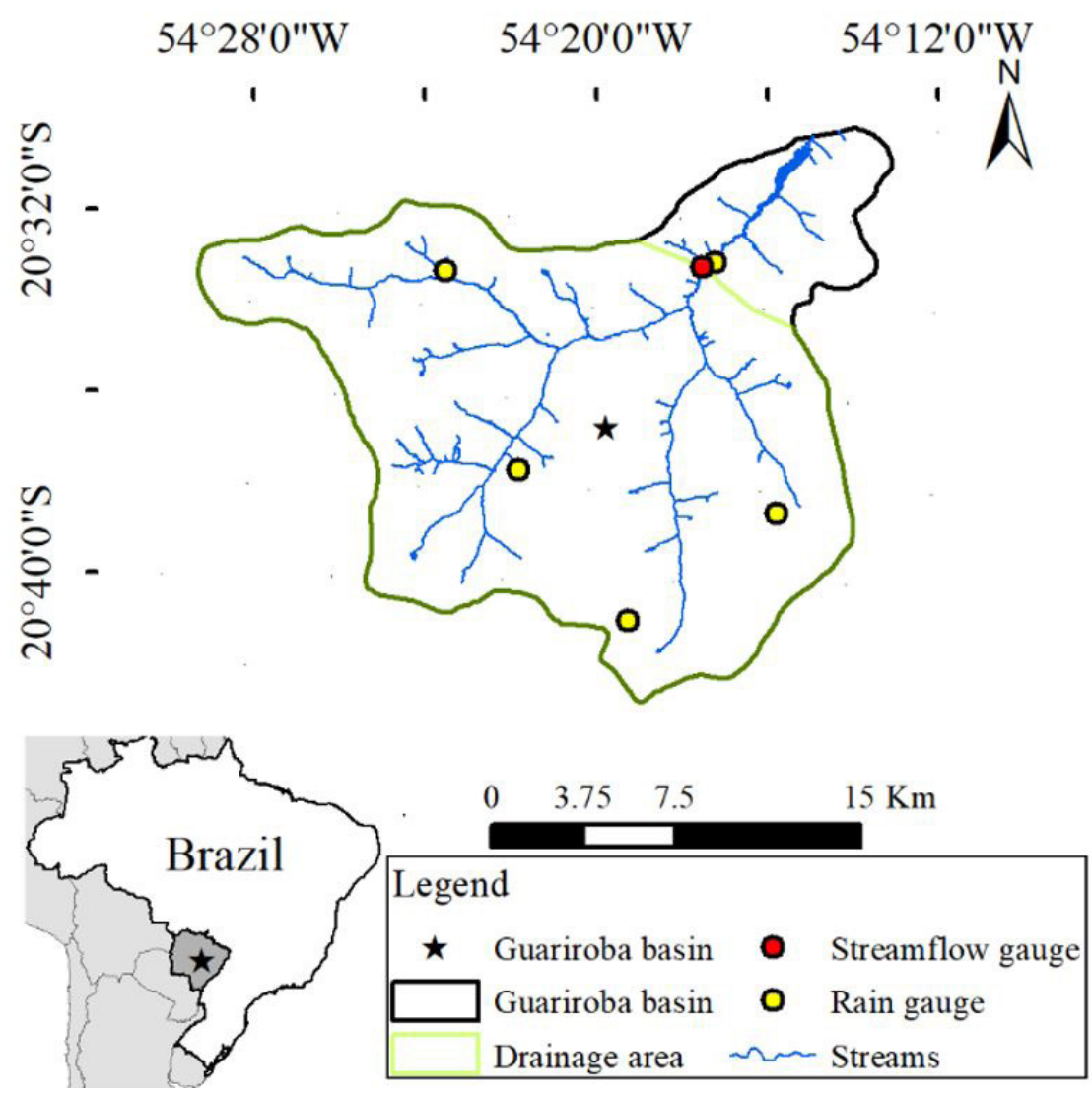

Figure 1. Location of the study area. The drainage area was delimited considering the streamflow gauge as the basin outlet and is highlighted in green. 
According to the Köppen climate classification system, the climate in the studied watershed is Am, humid tropical, with a dry winter (April through September) and a hot and rainy summer (October through March). The average annual temperature and precipitation are $23.3^{\circ} \mathrm{C}$ and $1400 \mathrm{~mm}$, respectively (CAMPO GRANDE, 2008). The rainfall events are mostly generated by convection, causing storms with high intensity. The elevation varies between 465 and $660 \mathrm{~m}$, and the average slope steepness is $3.7 \%$.

The predominant land use in the studied basin is pastures livestock (Table 1). According to the Brazilian Soil Classification System (SiBCS), the soil is classified as Orthic Quartzarenic Neosol - RQo with sandy texture (95.71\%), Dystrophic Red Latosol - LVd with sandy loam texture $(0.52 \%)$, and Hydromorphic Quartzarenic Neosol - RQg with sandy texture (3.77\%). We classified LVd in hydrologic soil group B, and RQo and RQg in hydrologic soil group A due to high infiltration rates (LIMA, 2016; USDA, 1997). Figure 2 shows the soil classes, hydrologic soil group classification and land uses for the studied area.

Table 1. Land use of the drainage area.

\begin{tabular}{lrc}
\hline \multicolumn{1}{c}{ Land use } & Area (ha) & Percentage (\%) \\
\hline Pastures & 23128.91 & $73.27 \%$ \\
Broad-leaved forest & 3618.43 & $11.46 \%$ \\
Moors and heathland & 647.99 & $2.05 \%$ \\
Transitional woodland-shrub & 434.98 & $1.38 \%$ \\
Sparsely vegetated areas & 477.74 & $1.51 \%$ \\
Inland marshes & 1009.03 & $3.20 \%$ \\
Water bodies & 39.56 & $0.13 \%$ \\
Eucalyptus & 2210.49 & $7.00 \%$ \\
\hline
\end{tabular}

a)

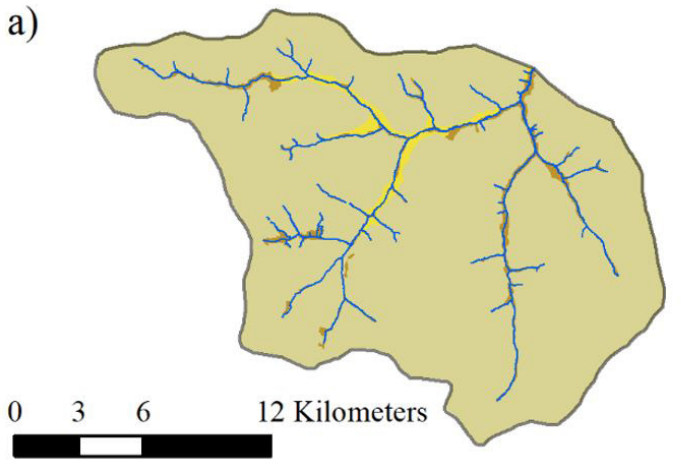

b)

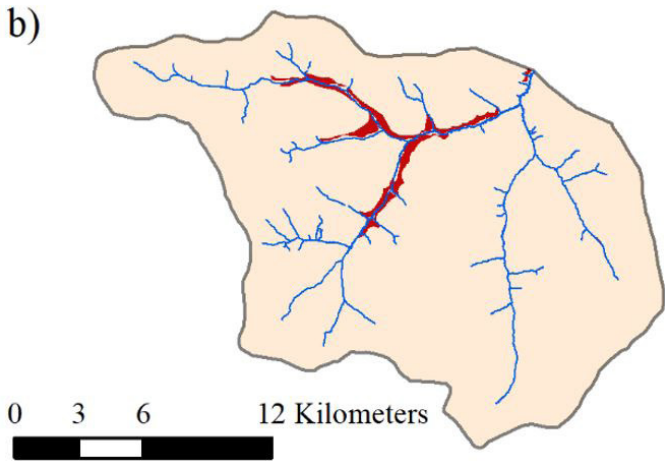

\section{Observed rainfall-runoff events}

We measure rainfall-runoff events during the years of 2015 and 2017. To measure rainfall depth at 10-minute intervals we used 5 automated tipping bucket rain gauges (PluvReg model S1610, Squitter) (Figure 1). To represent the average rainfall over the study area, we used the Thiessen Polygon method. In this study, we used only rainfall events higher than $\sim 1$ inch $(25.4 \mathrm{~mm})$ (HAWKINS; HJELMFELT JUNIOR; ZEVENBERGEN, 1985), totalizing 30 rainfall events, which ranged from 22.6 to $88.1 \mathrm{~mm}$.

Streamflow values were obtained by converting water levels located at the basin outlet (Figure 1). The water levels were recorded every 10 minutes using a pressure transducer sensor (Levelogger Junior Edge model 3001 LT, Solinst). These data were compared with mechanical current-meter method, which was performed every 30 days. Stream discharge was computed by a rating curve which parameters were optimized. The average streamflow discharge is $5.93 \mathrm{~m}^{3} \cdot \mathrm{s}^{-1}$, and mean annual surface runoff of $581 \mathrm{~mm}$. The direct runoff was calculated dividing the direct runoff volume of the event by the considered watershed area.

Thus, for hydrograph analysis, an Eckhardt based digital filtering analysis that performs as a low-pass filter for the water body (ECKHARDT, 2005) was applied to daily data, separating averaged streamflow $\left(\mathrm{y}_{\mathrm{k}}\right)$ into baseflow $\left(\mathrm{b}_{\mathrm{k}}\right)$ and direct runoff using the Web based Hydrograph Analysis Tool (WHAT), developed by Lim et al. (2005).

$b_{k}=\frac{\left(1-B F I_{\max }\right) \in b_{k-1}+(1-\epsilon) B F I_{\max } y_{k}}{1-\epsilon B F I_{\max }}$

where $\mathrm{k}$ is the time step, $\epsilon$ is the filter parameter, and BFImax is the maximum value of the baseflow index. Baseflow index represents how extensive groundwater contributes to total flow.
$\stackrel{N}{c})$
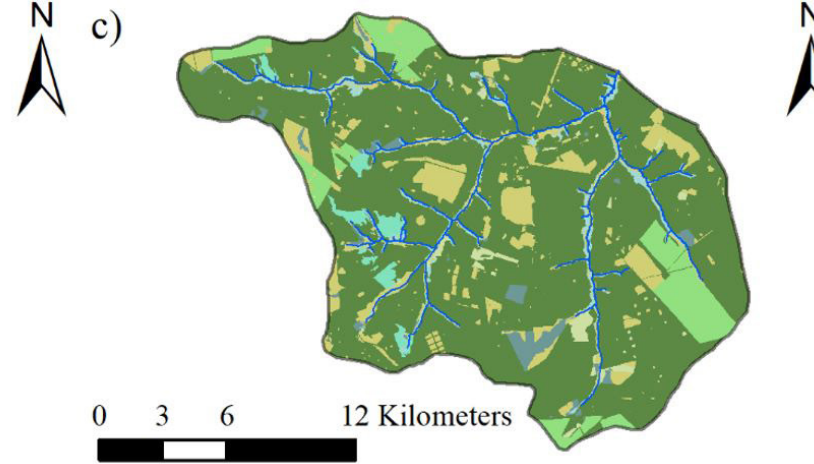

$\mathrm{N}$
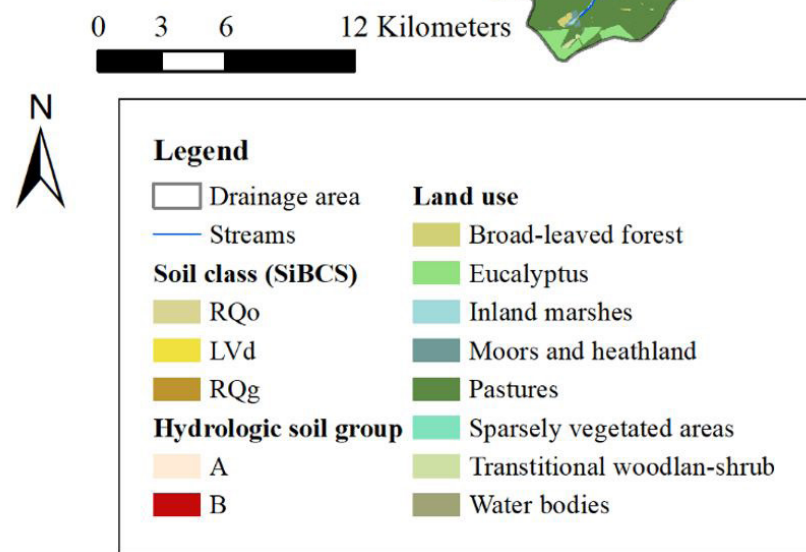

Figure 2. Soil classes (a), hydrologic soil group (b), and land uses (c) maps for the study drainage area. 
Eckhardt (2005) suggests BFImax value of $\sim 0.80$ for perennials streams with porous aquifers, which are the Guariroba basin streams characteristics, and $\epsilon$ value of 0.98 .

\section{SCS-CN method}

The SCS-CN method is based on the water balance equation to estimate storm runoff:

$Q=P-I a-F$

$\frac{Q}{P-I a}=\frac{F}{S}$

$I a=\lambda \times S$

where $\mathrm{P}$ is the precipitation $(\mathrm{mm}), \mathrm{Q}$ is the direct runoff $(\mathrm{mm})$, Ia is the initial abstraction $(\mathrm{mm})$, and $\mathrm{F}$ is the surface retention $(\mathrm{mm}), \mathrm{S}$ is the potential maximum retention after beginning of the runoff $(\mathrm{S} \geq \mathrm{F})(\mathrm{mm})$, and $\lambda$ is the initial abstraction ratio. The runoff $(\mathrm{Q})$ is obtained from the combination of Equations 2,3 , and 4 for $\mathrm{F}=\mathrm{P}-\mathrm{Q}$.

$Q=\frac{(P-I a)^{2}}{(P-I a)+S}$

Equation 2 is valid for $\mathrm{P}>\mathrm{Ia}$, otherwise, $\mathrm{Q}=0$, and the parameter $\mathrm{S}$ in Equations 3, 4, and 5 is defined as:

$S=\frac{25400}{C N}-254$

\section{Calculation of the initial abstraction ratio}

We computed the initial abstraction (Ia) considering the rainfall depth for each event until the direct runoff begin. After, the potential maximum retention (S) was obtained using the Equation 5. Then, the event $\lambda$ was computed using the Equation 4 . The median value of these obtained ratios was used as a representative value for the studied watershed, as described by Shi et al. (2009).

Considering $\lambda=0.2$, the values of $\mathrm{S}$ can be computed from Equation 7 after algebraic calculations for $\mathrm{S}, \mathrm{Q}$, and $\mathrm{P}$ in mm (HAWKINS, 1993):

$S_{0.2}=5\left[(P+2 Q)-\sqrt{4 Q^{2}+5 P Q}\right]$

Woodward et al. (2003) identified $\lambda=0.05$ would be more appropriate for use in runoff calculations, as this value produced a greater coefficient of determination $\left(\mathrm{R}^{2}\right)$ and a smaller standard error (SE) than 0.2. For $\lambda=0.05$, Equation 7 becomes:

$$
S_{0.05}=10\left[(2 P+19 Q)-\sqrt{361 Q^{2}+80 P Q}\right]
$$

Recent ongoing work in American Society of Civil Engineers (ASCE)-NRCS collaboration suggests a linear relationship between S0.2 and S0.05 (USDA, 2017). Considering this linear proportionality, the relation between $\mathrm{S} 0.2$ and S0.05 is:
$S_{0.05}=a \times S_{0.2}$

where $\mathrm{a}$ is the slope of S0.05 and S0.2.

\section{Estimation of Curve Number from rainfall-runoff data}

$\mathrm{CN}$ values obtained from rainfall-runoff data were computed by five procedures: the median (USDA, 1997); geometric mean (TEDELA et al., 2012); arithmetic mean (BONTA, 1997); nonlinear, least squares fit (HAWKINS, 1993); and standard asymptotic fit (HAWKINS, 1993).

The $\mathrm{CN}$ was obtained from Equation 6 using rainfall-runoff measured and computed S. We used these results to obtain $\mathrm{CN}$ by the median and mean methods.

The geometric mean was found using the logarithm of each maximum potential retention $\mathrm{S}$ value according to Equations 7 and $8, \log \mathrm{S}$; determined the arithmetic mean of the time series, $\overline{\log S}$; and then estimated the geometric mean S, $10^{\overline{\log S}}$. Then, we computed the curve number using the Equation 10:

$C N=\frac{100}{\left(1+\frac{10^{\overline{\log S}}}{254}\right)}$

For nonlinear, least squares fit method, we minimized the sum of squared differences between observed and $\mathrm{CN}$-calculated using Equation 5 for each rainfall-runoff event was minimized.

For standard asymptotic fit method, the rainfall and runoff series were ranked and matched in pairs from a decreasing order, and then calculating $S$ values from Equations 7 and 8 and $C N$ values via Equation 6. Hawkins (1993) found three types of behavior: standard, complacent, and violent. The standard behavior occurs when the $\mathrm{CN}$ declines with rising storm size approaching and/or maintaining a near constant value, $\mathrm{CN} \infty$, with increasingly larger storms. For standard behavior, was used Equation 11 (HAWKINS, 1993):

$C N(P)=C N_{\infty}+\left(100-C N_{\infty}\right) e^{-k P}$

where $\mathrm{k}$ is the fitting coefficient that describes the $\mathrm{CN}$ approach to $\mathrm{CN} \infty$

For complacent behavior, in which the observed $\mathrm{CN}$ declines steadily with increasing storm size without approaching a constant value, the runoff is more properly modelled by the linear form $\mathrm{Q}=\mathrm{CP}$ than by Equation 11 (HAWKINS; WARD; WOODWARD, 2009), where $\mathrm{C}$ is the runoff coefficient. Therefore, in this case it is not suitable to estimate $\mathrm{CN}$ using asymptotic fit method (HAWKINS, 1993).

We obtained Tabulated $\mathrm{CN}$ values for each land use considering the cover class, hydrologic conditions, and hydrologic soil group. The $\mathrm{CN}$ for the drainage area was computed by weighted average as CN0.2, since NCRS considers $\lambda=0.2$ (USDA, 1986). The S0.2 was found by Equation 6 using the $\mathrm{CN} 0.2$ value obtained by weighted average, and we used it to calculate $\mathrm{CN} 0.05$ value by Equations 9 and 6. We assumed $\mathrm{CN}$ values as ARC (antecedent runoff conditions) II, which represents an average moisture condition (USDA, 1997). 


\section{Uncertainties and statistical analyses}

The uncertainties were assessed for $\mathrm{CN}$ estimates. We compute uncertainties for the median method as the range of $\mathrm{CN}$ found from each rainfall-runoff event. We used the standard deviation computed from all $\mathrm{CN}$ values estimated for geometric and arithmetic mean methods. The standard error (SE) was used for nonlinear, least squares fit and asymptotic method (Equation 12):

$$
S E=\sqrt{\frac{\sum_{i=1}^{n}\left(Q_{o b s}-Q_{e s t}\right)^{2}}{n}}
$$

where $Q_{e s t}$ and $Q_{o b s}$ are values of estimated and observed runoff, respectively, considering the pair $i$ from the $\mathrm{CN}$ found by each studied method and the number of rainfall-runoff events (n).

For statistical analysis was used the coefficient of determination $\left(\mathrm{R}^{2}\right)$, Equation 13, percentage mean bias, Equation 14, and the Nash-Sutcliffe Efficiency (NSE) (NASH; SUTCLIFFE, 1970), Equation 15.

$$
\begin{aligned}
& R^{2}=\left\{\frac{\sum_{i=1}^{n}\left(Q_{o b s}-\bar{Q}_{o b s}\right)\left(Q_{e s t}-\bar{Q}_{e s t}\right)}{\left[\sum_{i=1}^{n}\left(Q_{o b s}-\bar{Q}_{o b s}\right)^{2} \times \sum_{i=1}^{n}\left(Q_{e s t}-\bar{Q}_{e s t}\right)^{2}\right]^{0.5}}\right\}^{2} \\
& \text { PBIAS }=\left[\frac{\sum_{i=1}^{n}\left(Q_{o b s}--Q_{e s t}\right) \times 100}{\sum_{i=1}^{n}\left(Q_{o b s}\right)}\right]
\end{aligned}
$$
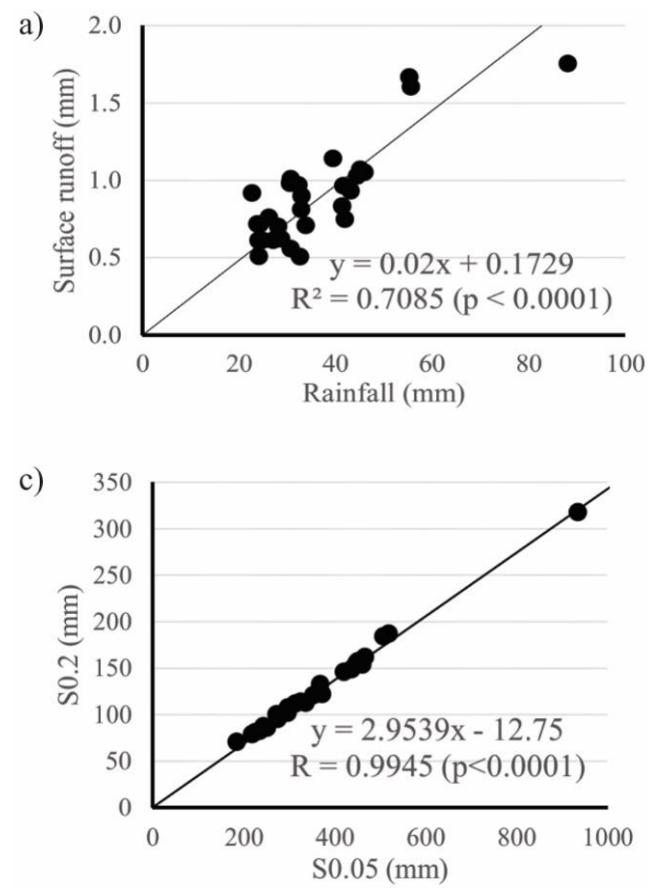

$$
N S E=1-\left[\frac{\sum_{i=1}^{n}\left(Q_{e s t}-Q_{o b s}\right)^{2}}{\sum_{i=1}^{n}\left(Q_{o b s}-\bar{Q}_{o b s}\right)^{2}}\right]
$$

where $\bar{Q}_{\text {est }}$ and $\bar{Q}_{\text {obs }}$ are average values of estimated and observed runoff, respectively.

The PBIAS is expected to be close to zero when the model is accurate to estimate the streamflow. Positive values indicate model underestimation bias and negative ones. The PBIAS can be considered "very good" if PBIAS $< \pm 10 \%$; "good", if $10 \% \leq$ PBIAS < $<15 \%$; "satisfactory", if $15 \% \leq$ PBIAS $< \pm 25 \%$; and "unsatisfactory", if PBIAS $\geq \pm 25 \%$. $\mathrm{R}^{2}$ greater than 0.5 is considered "acceptable". NSE values ranges from $-\infty$ to 1 , and can be considered as "very good" if $0.75<\mathrm{NSE} \leq 1$; "good", if $0.65<\mathrm{NSE} \leq 75$; "satisfactory", if $0.50<\mathrm{NSE} \leq 0.65$; and "unsatisfactory”, if NSE $\leq 0.50$ (MORIASI et al., 2007).

\section{RESULTS AND DISCUSSION}

\section{Initial abstraction ratio based on rainfall-runoff event analysis}

Thirty rainfall-runoff events were analyzed (Figure $3 a$ ) and was found a greatly variation ranges on the initial abstraction $(\lambda)$ values. The median value of $\lambda$ to the studied watershed was equal to 0.045 , with values ranging from 0.005 to 0.455 (Figure $3 \mathrm{~b}$ ). We noted that $96.7 \%$ of the $\lambda$ values were smaller than 0.2 (standard value used in the SCS-CN method). Similar results were reported by Woodward et al. (2003) and Shi et al. (2009).
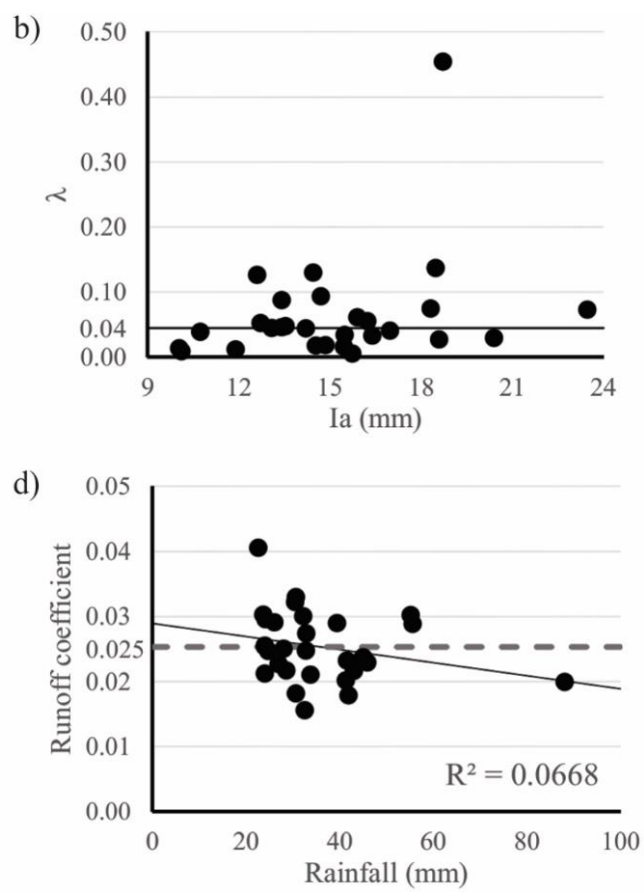

Figure 3. Plots of the 30 rainfall-runoff events for (a) surface runoff depth (Q) versus rainfall depth (P); (b) initial abstraction ratio $(\lambda)$ versus initial abstraction $\left(\mathrm{I}_{\mathrm{a}}\right)$; (c) correlation between the values computed for S0.05 and S0.2; and (d) runoff coefficient (C) values versus observed rainfall. For figures (a), (c), and (d) the black line is the linear regression for each data set. For figure b the black line is the median. For figure $d$ the dashed line represents the mean value. Figures a and c showed significant statistics, but figure $d$ did not show a significant fit. Therefore, linear correlation should not be considered in figure d. 
Furthermore, several authors have reported $\lambda \neq 0.2$ (AJMAL; KIM, 2014; DURÁN-BARROSO; GONZÁLEZ; VALDÉS, 2017; ELHAKEEM; PAPANICOLAOU, 2009; LAL et al., 2016; YUAN et al., 2014). Therefore, our results indicated that is more appropriate to use a $\lambda$ of 0.05 for the Guariroba basin, due to small difference between the observed $\lambda(0.045)$ and $\lambda=0.05$, which was suggested by Woodward et al. (2003). Our findings also corroborates with recent suggestion from the (ASCE)-NRCS in to use of $\lambda=0.05$ instead of $\lambda=0.2$ (USDA, 2017).

Initial abstraction consists mainly of interception, infiltration during early parts of the storm, and surface depression storage (USDA, 1997). The Guariroba basin presents flat areas (average slope steepness of $3.7 \%$ ) with small variation in the elevation. For the most part of the soils in this basin are classified in the Brazilian Soil Classification System (SiBCS) as Ortic Quartzarenic Neosol (RQo) (95.71\%) with sandy texture in the entire profile (less than 15\% clay). In an experimental study using a rainfall simulator in the Guariroba basin, Lima (2016) found infiltration rate values under pastures ranging from 71.5 to $106.1 \mathrm{mmh}^{-1}$. This high value of infiltration rate is significant, mainly because pastures cover $73.27 \%$ of the drainage area of the studied basin. Therefore, in the Guariroba basin, the topography, soil characteristics, and land cover provide relatively small amounts of runoff and a rapid infiltration of water into the soil.

\section{CN values}

The $\mathrm{CN}$ values found for the watershed are shown in Table 2. For $\lambda=0.2, \mathrm{CN}$ values varied from 53.1 (nonlinear, least squares) to 69.3 (median). For $\lambda=0.05, \mathrm{CN}$ values varied from 17.7 (nonlinear, least squares) to 44.3 (median). The recommended slope a between S0.05 and S0.2 from (Equation 9), when its value is not known, is 1.42 (USDA, 2017), however, we found a value of 2.865 for the Guariroba basin (Figure 3c). Table 2 also shows the evaluation of each method. For every method used, except to the standard asymptotic method, we found negative values of NSE, which suggest a poor fit between observed and estimated runoff (OLIVEIRA et al., 2016).

Some authors have also reported poor performance of the SCS-CN method in regions that provide high infiltration rates, such as forested areas (TEDELA et al., 2012) and areas with predominant sand soils (OLIVEIRA et al., 2016). This poor performance likely happens because the runoff mechanisms in these areas may be dominated by subsurface stormflow (BARTLET'T et al., 2016).

The central tendencies methods (median, geometric mean, and arithmetic mean) and tabulated $\mathrm{CN}$ values overestimated surface runoff (negative bias). For nonlinear, least squares fit, the $\mathrm{CN}$ found for $\lambda=0.2$ also overestimated runoff, however, $\mathrm{CN}$ value for $\lambda=0.05$ underestimated runoff (positive bias). Surface runoff estimated using $\lambda=0.2$ were found to be more overestimated than runoff computed using $\lambda=0.05$.

Complacent behavior was found for $\lambda=0.2$ (Figure 4a) by standard asymptotic method, and thus the $\mathrm{CN}$ found is not suitable (HAWKINS; WARD; WOODWARD, 2009). In the present study we have used a short time series of rainfall and runoff, therefore it is important to make clear that a longer time series may show a standard or violent behavior for the studied basin. Standard behaviour was found in the plot for $\lambda=0.05$ (Figure 4b) with a $\mathrm{CN} \infty$ value of 21.2 (Table 3). The $\mathrm{CN}$ with higher coefficient of determination $\left(\mathrm{R}^{2}\right)$ and NSE were found to be estimated using standard asymptotic for $\lambda=0.05$. However, the $\mathrm{CN} \infty$ value found is smaller than 30 , the minimum $\mathrm{CN}$ value recommended for computations (USDA, 1986). Considering $\mathrm{CN} \infty$ value for $\lambda=0.05$ as 30 (Figure $4 \mathrm{c}$ ), we found negative value of NSE (Table 3), therefore, asymptotic method is considered unsatisfactory for tropical watersheds with similar characteristics than the Guariroba basin.

Table 2. Estimated curve numbers (and uncertainty ranges) and evaluation of each method with observer runoff values.

\begin{tabular}{|c|c|c|c|c|}
\hline \multirow{2}{*}{ Method } & \multicolumn{4}{|c|}{$\lambda=0.2$} \\
\hline & $\mathrm{CN}$ & $\mathbf{R} 2$ & NSE & PBIAS (\%) \\
\hline NRCS table & 64.8 & 0.575 & -114.661 & -90.505 \\
\hline Median & 69.2 (44.4 to 78.3$)$ & 0.637 & -225.861 & -208.074 \\
\hline Arithmetic mean & $67.1(59.2$ to 75.1$)$ & 0.612 & -166.239 & -146.554 \\
\hline Geometric mean & 67.5 (59.6 to 75.5$)$ & 0.618 & -176.834 & -157.903 \\
\hline \multirow[t]{3}{*}{ Nonlinear, leastsquares } & 52.4 (51.0 to 53.9) & 0.017 & -16.963 & -38.781 \\
\hline & \multicolumn{4}{|c|}{$\lambda=0.05$} \\
\hline & $\mathrm{CN}$ & $\mathbf{R} 2$ & NSE & PBIAS (\%) \\
\hline NRCS table & 39.1 & 0.593 & -25.468 & -12.716 \\
\hline Median & 44.3 (21.4 to 58.0$)$ & 0.644 & -59.452 & -102.778 \\
\hline Arithmetic mean & 42.6 (34.0 to 51.2$)$ & 0.637 & -47.009 & -76.873 \\
\hline Geometric mean & $42.3(33.7$ to 50.9$)$ & 0.636 & -45.208 & -72.850 \\
\hline Nonlinearleast, squares & $17.9(17.1$ to 18.6$)$ & 0.330 & -3.325 & 38.104 \\
\hline
\end{tabular}

Table 3. Fitting statistics for standard asymptotic fit method.

\begin{tabular}{lccccc}
\hline \multicolumn{1}{c}{$\mathbf{C N}_{\infty}$} & $\boldsymbol{\lambda}$ & $\mathbf{k}\left(\mathbf{m m}^{-1}\right)$ & $\mathbf{R}^{\mathbf{2}}$ & $\mathbf{N S E}$ & PBIAS (\%) \\
\hline $31.7(30.9$ to 32.5$)$ & 0.20 & 0.038 & 0.589 & 0.399 & 91.587 \\
$21.2(23.0$ to 19.4$)$ & 0.05 & 0.038 & 0.589 & 0.399 & 91.587 \\
30.0 & 0.05 & 0.049 & 0.566 & -4.554 & -19.678 \\
\hline
\end{tabular}

$\mathrm{k}$ is the fitting coefficient that describes the $\mathrm{CN}$ approach to $\mathrm{CN} \propto ; \lambda$ is the initial abstraction ratio; $\mathrm{R}^{2}=$ coefficient of determination; NSE = Nash-Sutcliffe Efficiency; PBIAS = percentage mean bias; $\mathrm{CN} \infty$ and $\mathrm{k}$ are fitted from the asymptotic equation (Equation 11). 

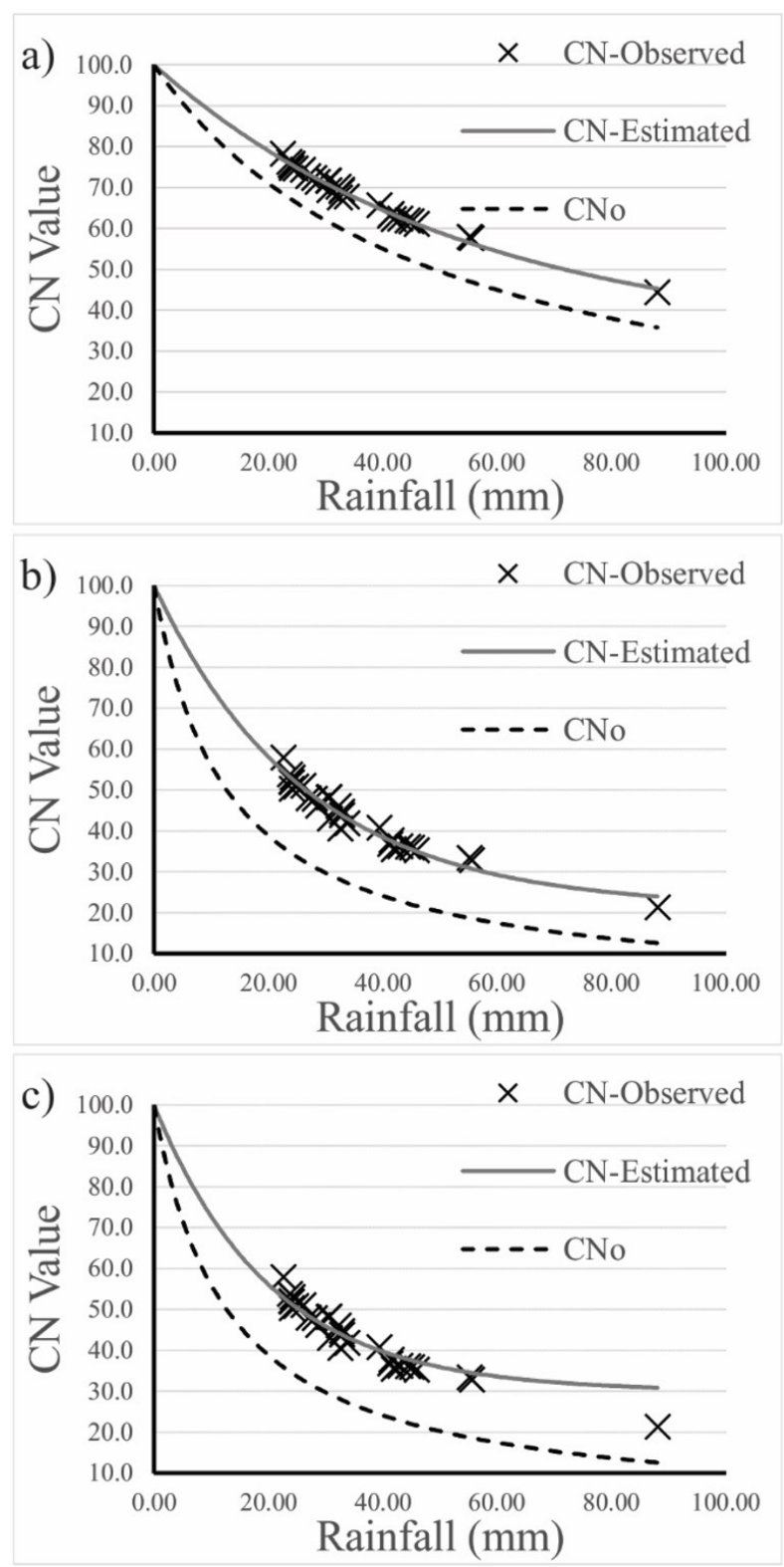

Figure 4. Asymptotic fit method plots for Guariroba basin using rank-ordered rainfall and runoff. Figure (a) refers to plot with $\lambda=0.2$. Figures (b) and (c) refer to plot with $\lambda=0.05$ with calculated $\mathrm{CN} \infty$ and $\mathrm{CN} \infty=30$, respectively. The $\mathrm{CNo}$ is the threshold under which no runoff is projected to occur $(\mathrm{P}=\lambda \mathrm{S})$ and was computed by equation $\mathrm{CNo}=25,400 /[(\mathrm{P} / \lambda)+254]$, for $P$ in millimeters.

In complacent behavior the runoff coefficients (C) (total runoff divided by total rainfall) usually range from 0.005 to 0.05 (HAWKINS; WARD; WOODWARD, 2009). Oliveira et al. (2016) found runoff coefficient ranging from 0.001 to 0.030 for the undisturbed Cerrado (Brazilian Savannah). In the present study, the runoff coefficient for the watershed ranged from 0.016 to 0.041 , with an average of 0.025 (Figure 3d). Observed $C$ values did not increase as rainfall depths increase. This result corroborates with the complacent behavior found in the present study and with the characteristics of the Guariroba basin that provide relatively small amounts of runoff.
As we found complacent behavior and negative values of NSE we can suggest that the $\mathrm{CN}$ method was not suitable to estimate runoff in studied basin. Thus, is more appropriate to compute runoff by the equation $\mathrm{Q}=\mathrm{CP}$, where $\mathrm{C}$ is the runoff coefficient, since the $\mathrm{CN}$ method is not suitable for these cases (OLIVEIRA et al., 2016). In this context, we computed runoff using the average runoff coefficient $(0.025)$ by the equation $\mathrm{Q}=\mathrm{CP}$ and compare with observed runoff. Our findings showed a good model performance with values of $\mathrm{R}^{2}$, NSE, and PBIAS of 0.71 , 0.66 , and -2.02 , respectively. These results highlight the importance of future investigations about the use of the $\mathrm{CN}$ method in tropical watersheds, such as that developed in the present study and by Andrade et al. (2017), Oliveira et al. (2016), and Sartori, Hawkins and Genovez (2011).

\section{CONCLUSIONS}

In this study, we investigated the initial abstraction ratio ( $\lambda$ ) and $\mathrm{CN}$ values to a rural basin located in Midwestern Brazil. $\mathrm{CN}$ values were computed from the measured data using five different statistical methods. We used 30 rainfall-runoff events with an amount of rainfall events ranging from 22.6 to $88.1 \mathrm{~mm}$.

Our results indicated that $\lambda$ values varied from 0.005 to 0.455 , with a median of 0.045 . Therefore, we recommend the use of $\lambda$ of 0.05 instead of 0.2 to other watersheds with similar characteristics than the Guariroba basin.

We noted complacent behavior and negative values of Nash-Sutcliffe Efficiency NSE (to the estimated and observed runoff). Then, our findings suggested that the $\mathrm{CN}$ was inappropriate to compute surface runoff in the studied basin. This poor performance likely happened because the runoff mechanisms in the Guariroba basin may be dominated by subsurface runoff.

\section{ACKNOWLEDGEMENTS}

This study was supported by grants from the Ministry of Science, Technology, Innovation and Communication - MCTIC and National Council for Scientific and Technological Development - CNPq (441289/2017-7 and 306830/2017-5). This study was also financed in part by the Coordenação de Aperfeiçoamento de Pessoal de Nível Superior - Brasil (CAPES) - Finance Code 001”.

\section{REFERENCES}

AJMAL, M.; KIM, T.-W. Quantifying excess stormwater using SCS-CN-based rainfall runoff models and different curve number determination methods. Journal of Irrigation and Drainage Engineering, v. 141, n. 3, p. 363-370, 2014.

AJMAL, M.; WASEEM, M.; AHN, J.-H.; KIM, T.-W. Improved runoff estimation using event-base rainfall-runoff models. Water Resources Management, v. 29, n. 6, p. 1995-2010, 2015. http://dx.doi. org/10.1007/s11269-015-0924-z.

ANDRADE, E. M.; ARAÚJO NETO, J. R.; GUERREIRO, M. J. S.; SANTOS, J. C. N.; PALÁCIO, H. A. Q. Land use effect on the $\mathrm{CN}$ model parameters in a tropical dry environment. Water 
Resources Management, v. 31, n. 13, p. 4103-4116, 2017. http:// dx.doi.org/10.1007/s11269-017-1732-4.

BARTLETT, M. S.; PAROLARI, A. J.; MCDONNELL, J. J.; PORPORATO, A. Beyond the SCS-CN method: a theoretical framework for spatially lumped rainfall-runoff response. Water Resources Research, v. 52, n. 6, p. 4608-4627, 2016. http://dx.doi. org/10.1002/2015WR018439.

BONTA, J. V. Determination of watershed curve number using derived distributions. Journal of Irrigation and Drainage Engineering, v. 123, n. 1, p. 28-36, 1997. http://dx.doi.org/10.1061/(ASCE)07339437(1997)123:1(28).

CAMPO GRANDE. Prefeitura Municipal. Plano de manejo da Área de Proteção Ambiental dos mananciais do córrego Guariroba - APA do Guariroba. Campo Grande, 2008. v. 1.

DURÁN-BARROSO, P.; GONZÁLEZ, J.; VALDÉS, J. B. Sources of uncertainty in the NRCS CN model: recognition and solutions. Hydrological Processes, v. 31, n. 22, p. 3898-3906, 2017. http://dx.doi. org/10.1002/hyp.11305.

ECKHARDT, K. How to construct recursive digital filters for baseflow separation. Hydrological Processes, v. 19, n. 2, p. 507-515, 2005. http://dx.doi.org/10.1002/hyp.5675.

ELHAKEEM, M.; PAPANICOLAOU, A. N. Estimation of the runoff curve number via direct rainfall simulator measurements in the state of Iowa, USA. Water Resources Management, v. 23, n. 12, p. 2455-2473, 2009. http://dx.doi.org/10.1007/s11269-008-9390-1.

HAWKINS, R. H. Asymptotic determination of runoff curve numbers from data. Journal of Irrigation and Drainage Engineering, $\mathrm{v}$. 119, n. 2, p. 334-345, 1993. http://dx.doi.org/10.1061/(ASCE)07339437(1993)119:2(334).

HAWKINS, R. H.; WARD, T. J.; WOODWARD, D. E. Curve number bydrology: the state of practice. Reston: American Society of Engineers, 2009.

HAWIKINS, R. H.; HJELMFELT JUNIOR, A. T.; ZEVENBERGEN, A. W. Runoff probability, storm depth, and curve numbers. Journal of Irrigation and Drainage Engineering, v. 111, n. 4, p. 330-340, 1985. http://dx.doi.org/10.1061/(ASCE)0733-9437(1985)111:4(330).

LAL, M.; MISHRA, S. K.; PANDEY, A.; PANDEY, R. P.; MEENA, P. K.; CHAUDHARY, A.; JHA, R. K.; SHREEVASTAVA, A. K.; KUMAR, Y. Evaluation of the Soil Conservation Service curve number methodology using data from agricultural plots. Hydrogeology Journal, v. 25, n. 1, p. 151-167, 2016. http://dx.doi. org/10.1007/s10040-016-1460-5.

LIM, J. K.; ENGEL, B. A.; TANG, Z.; CHOI, J.; KIM, K.-S.; MUTHUKRISHNAN, S.; TRIPATHY, D. Automated Web GIS based hydrograph analysis tool, what. Journal of the American Water Resources Association, v. 41, n. 6, p. 1407-1416, 2005. http://dx.doi. org/10.1111/j.1752-1688.2005.tb03808.x.

LIMA, F. E. Perda de solo e infiltração de água em diferentes sistemas de cultivo. 2016. 68 f. Dissertação (Mestrado em Tecnologias
Ambientais) - Universidade Federal de Mato Grosso do Sul, Campo Grande, 2016.

MORIASI, D. N.; ARNOLD, J. G.; VAN LIEW, M. W.; BINGNER, R. L.; HARMEL, R. D.; VEITH, T. L. Model evaluation guidelines for systematic quantification of accuracy in watershed simulations. Transactions of the ASABE, v. 50, n. 3, p. 885-900, 2007. http:// dx.doi.org/10.13031/2013.23153.

NASH, J. E.; SUTCLIFFE, J. V. River flow forecasting through conceptual models part I: a discussion of principles. Journal of Hydrology, v. 10, n. 3, p. 282-290, 1970. http://dx.doi.org/10.1016/00221694(70)90255-6.

OLIVEIRA, P. T. S.; NEARING, M. A.; HAWKINS, R. H.; STONE, J. J.; RODRIGUES, D. B. B.; PANACHUKI, E.; WENDLAND, E. Curve number estimation from Brazilian Cerrado rainfall and runoff data. Journal of Soil and Water Conservation, v. 71, n. 5, p. 420-429, 2016. http://dx.doi.org/10.2489/jswc.71.5.420.

SARTORI, A.; HAWKINS, R. H.; GENOVEZ, A. M. Reference curve numbers and behavior for sugarcane on highly weathered tropical soils. Journal of Irrigation and Drainage Engineering-Asce, v. 137, n. 11, p. 705-711, 2011. http://dx.doi.org/10.1061/(ASCE) IR.1943-4774.0000354.

SHI, Z. H.; CHEN, L.-D.; FANG, N.-F.; QIN, D.-F.; CAI, C.-F. Research on the SCS-CN initial abstraction ratio using rainfall-runoff event analysis in the Three Gorges Area, China. Catena, v. 77, n. 1, p. 1-7, 2009. http://dx.doi.org/10.1016/j.catena.2008.11.006.

SOROOSHIAN, S.; HSU, K.-L.; COPPOLA, E.; TOMASSETTI, B.; VERDECCHIA, M.; VISCONTI, G. Hydrological modelling and the aater cycle. Berlin: Springer Berlin Heidelberg, 2008. v. 63. http:/ / dx.doi.org/10.1007/978-3-540-77843-1.

TEDELA, N. H.; MCCUTCHEON, S. C.; RASMUSSEN, T. C.; HAWKINS, R. H.; SWANK, W. T.; CAMPBELL, J. L.; ADAMS, M. B.; JACKSON, C. R.; TOLLNER, E. W. Runoff curve numbers for 10 small forested watersheds in the mountains of the eastern United States. Journal of Hydrologic Engineering, v. 17, n. 11, p. 1188-1198, 2012. http://dx.doi.org/10.1061/(ASCE) HE.1943-5584.0000436.

UNITED STATES DEPARTMENT OF AGRICULTURE USDA. Natural Resources Conservation Service - NRCS. Urban bydrology for small watersheds TR-55. Washington: USDA-NRCS, 1986.

UNITED STATES DEPARTMENT OF AGRICULTURE USDA. Natural Resources Conservation Service - NRCS. Part 630: hydrology national engineering handbook. Washington: USDA-NRCS, 1997.

UNITED STATES DEPARTMENT OF AGRICULTURE USDA. Ewri Curve Number Hydrology Task Committee. Estimation of direct runoff from storm rainfall (draft). Washington: USDA-NRCS, 2017. chap. 10. Available from: < https://directives.sc.egov.usda. gov $/$ OpenNonWebContent. aspx?content $=41607$.wba $>$. Access on: 2 aug. 2018. 
WOODWARD, D. E.; HAWKINS, R. H.;JIANG, R.; HJELMFELT JUNIOR, A. T.; VAN MULLEM, J. A.; QUAN, D. Q. Runoff curve number method: examination of the initial abstraction ratio. In: 2003 WORLD WATER AND ENVIRONMENTAL RESOURCES CONGRESS, 2003, Philadelphia. Proceedings... Reston: ASCE, 2003. p. 1-10.

YUAN, Y.; NIE, W.; MCCUTCHEON, S. C.; TAGUAS, E. V. Initial abstraction and curve number for semiarid watersheds in Southeastern Arizona. Hydrological Processes, v. 28, n. 3, p. 774-783, 2014. http://dx.doi.org/10.1002/hyp.9592.

\section{Authors contributions}

Luiz Claudio Galvão do Valle Junior: First author who contributed to literature review, discussion of results, as well as writing and formatting of the article.

Dulce Buchala Bicca Rodrigues: Contribution in the paper conception, literature review, discussion and paper writing.

Paulo Tarso Sanches de Oliveira: Research coordinator, paper conception, analysis and completion of results and discussion. 